\title{
Demographic characteristics in preeclamptic women in Macedonia
}

\author{
EMILIJA JASOVIC-SIVESKA ${ }^{1}$, VLADIMIR JASOVIC ${ }^{2}$
}

'MD, MSc, Gynecologist \& Obstetrician, PhD student. Policlinic Neuromedica, Bitola. ${ }^{2} \mathrm{MD}, \mathrm{MSc}$ of human reproduction. Clinical Hospital Bitola, Macedonia.

This study is part of the PhD thesis of Dr. Emilija Jasovic-Siveska.

We declare that there are no financial or other conflicts of interest. We take thus responsibility for the integrity of the data and accuracy of the data analysis.

Recibido el 5 de abril de 2010, aceptado el 12 de marzo de 2011.

Correspondence to

Dr. Emilija Jasovic-Siveska. Solunska 218 a Bitola. Republic of Macedonia.

Phone: +38970782 100 Fax: +389472422 24 E-mail:medihelp@t-home.

\begin{abstract}
Background: Worldwide, pre-eclampsia and eclampsia contribute to the death of a pregnant woman every three minutes. Aim: To determine the demographic risk factors and values of blood pressure to predict preeclampsia. Material and Methods: Demographic and clinical features of 300 normotensive pregnant women aged 28 \pm 5 years and 100 preeclamptic women aged $28 \pm 6$ years, were assessed. Women with multiple pregnancies were excluded from the study. Results: Women with less educational attainment had a higher risk of mild and severe preeclampsia. Weight gain during pregnancy in control and pre eclamptic women were $14 \pm 3$ and $20 \pm 5$ $\mathrm{kg}$, respectively $(p<0.01)$. Women with severe preeclampsia had high significantly shorter gestations then the other two patient groups $(p<0.01)$. Compared to normotensive women, at 6 to 12 weeks of gestation, pre eclamptic women had higher systolic (102 \pm 7 and $113 \pm 9 \mathrm{mmHg}$ respectively), diastolic ( $64 \pm 5$ and $74 \pm 10$ $\mathrm{mmHg}$ respectively) and mean arterial pressure ( $77 \pm 5$ and $87 \pm 8.01 \mathrm{mmHg}$ respectively). Conclusions: Women with basic education or illiterate have a higher risk of developing preeclampsia. During the first or second trimester of pregnancy, mean arterial pressure is the best predictor for preeclampsia.
\end{abstract}

(Rev Med Chile 2010; 139: 748-754).

Key words: Blood pressure; Pre-eclampsia; Pregnancy complications. Blood pressure.

\section{Características demográficas de mujeres con pre eclampsia en Macedonia}

Antecedentes: La pre eclampsia contribuye a la muerte de una mujer embarazada cada 3 minutos a nivel mundial. Objetivo: Analizar los factores de riesgo demográficos y los valores de presión arterial predictores de pre eclampsia. Material y Métodos: Se estudiaron las características demográficas y clínicas de 300 mujeres embarazadas con presión arterial normal de $28 \pm 5$ años y 100 mujeres con pre eclampsia de 28 \pm 6 años. Resultados: Las mujeres con menor nivel educacional tuvieron un riesgo mayor de presentar pre eclampsia moderada o severa. La ganancia de peso durante el embarazo de mujeres con pre eclampsia y presión normal fue de $20 \pm 5 \mathrm{~kg}$ y $14 \pm$ 3 , respectivamente $(p<0,01)$. Las mujeres con pre eclampsia severa tuvieron gestaciones significativamente más cortas que el resto de los grupos. Comparadas con mujeres normotensas, a las 6 a 12 semanas de gestación, las mujeres con pre eclampsia tenían mayor presión arterial sistólica (102 \pm 7 y $113 \pm 9 \mathrm{mmHg}$ respectivamente), diastólica (64 \pm 5 y $74 \pm 10 \mathrm{mmHg}$ respectivamente) y media (77 \pm 5 y $87 \pm$ 8,01 $m m H g$ respectivamente). Conclusiones: Las mujeres analfabetas o con educación básica tienen el mayor riesgo de desarrollar pre eclampsia. La presión arterial media durante el primer trimestre es el mejor predictor de preeclampsia. 
W orldwide, pre-eclampsia and eclampsia contribute to the death of a pregnant woman every 3 minutes. The management of pregnancies complicated by hypertension has not changed significantly for many years, possibly as result of little progress being made in our understanding of the condition ${ }^{1}$.

Preeclampsia (PE) is one of the most common medical problems in perinatology. $\mathrm{PE}$ is a multisystem disorder, of unknown etiology, usually associated with raised blood pressure and proteinuria ${ }^{2}$.

Generally, the identification of potential factors associated with PE in a given population requires a great effort. Previously described risk factors for $\mathrm{PE}$ include socio-demographical factors (extremes of reproductive age, socio-economic status, ethnic group), genetic factors, pregnancy factors (multiple pregnancies, primigravidae, previous preeclampsia) or personal medical history (obesity, chronic renal disease, chronic hypertension, diabetes mellitus, thrombophilia) $)^{3-7}$.

Several authors associate PE with obesity during pregnancy. Optimal weight gain should be $11-12,5 \mathrm{~kg}$ for single and $6-20 \mathrm{~kg}$ for multiple pregnancies. However, the estimate has to be individualized because it depends on the characteristics of the future mother (age, body weight before pregnancy, habits, ethnicity, etc) ${ }^{8}$. Eating habits are closely connected with excessive weight gain during pregnancy. Hypercaloric food, especially high in carbohydrate and fat, and low in proteins could cause a metabolic misbalance leading to $\mathrm{PE}^{6,8,9}$.

While some authors consider that there is a connection between PE and smoking, others disagree $^{10}$. Smoking during pregnancy reduces baby weight by 150-300 grams. Quitting smoking before the third trimester improves fetus health and weight. Smoking increases the concentration of carbohemoglobin in the maternal and fetal blood, which leads to relative fetal hypoxemia. Smoking also causes a release of adrenalin and noradrenalin, which can induce a spasm in uterine blood vessels and reduce their blood flow. The endothelium of fetal blood vessels of smoking mothers has lower amounts of prostacyclin (PGI2), also reducing fetal blood circulation ${ }^{11,12}$.

A large number of pregnancies with PE, especially the severe form, lacked an adequate antenatal surveillance. Active protection is very important in the prevention of preeclampsia and does not require special or expensive equipment. It is ne- cessary to treat every pregnancy as a potential PE at the beginning. Attention should be paid mainly to the high risk groups.

The aim of this research was to identify risk groups of pregnant women for PE and to identify risk factors for the condition.

\section{Material and Methods}

\section{Study population}

The research was conducted in the Clinical Hospital "Dr Trifun Panovski" in Bitola, Macedonia, Department of Gynaecology and Obstetrics. Patients studied were admitted between May 1st 2008 to August 1st 2009 The Ethics Committee of School of Medicine University of Belgrade, Serbia, approved the experimental study protocol. The participants were included in the study after written informed consent was obtained. The final study included 400 previously healthy women aged 15 to 43 years, (300 normotensive and 100 with $\mathrm{PE}$ ), with no history of any chronic disease, with singleton pregnancies, without chromosomal or congenital abnormalities, with a known date of the last menstrual period and regular previous menstrual periods.

The criteria to determine the exact pregnancy stage was based on anamnestic data, obstetrical and ultrasound examinations, which means that the information of the last period was in concordance with the results from obstetrical and ultrasound examinations. The first assessment was performed at 6 to 12 weeks of gestation $(\mathrm{wg})$.

\section{Definition of study variables}

Age, education, nationality, parity, smoking status, week of $\mathrm{PE}$ onset, duration of $\mathrm{PE}$, duration of pregnancy, birth weight and length, and birth weight in percentiles, were assessed. Smoking status and level of education were determined by self-report.

All subjects were followed until delivery. The gestational age at delivery, obstetric complications if any, and neonatal outcome were recorded. For those subjects who subsequently delivered in another hospital, the obstetric information was obtained telephoning the subject or contacting the staff in the other hospital. Birth weight (to the nearest gram) was classified into five categories: very low birth weight ( $<5$ th percentile), low 
(5 -9,9), normal (10-89.9), high (90-94.9) and very high $(>95)$.

Prepregnancy BMI was determined based on measured height and maternal weight at the initial visit (6-12 w.g.) and maternal self report of prepregnancy weight. Height was measured by using a portable stadiometer, accurate to $1 \mathrm{~mm}$. Weight was determined by using the average of two measurements, with the woman lightly clothed. A scale accurate to $0.2 \mathrm{~kg}$ was used. Pre-pregnancy BMI was categorized as: underweight $(<19.9)$, normal (20.0-24.9), overweight (25.0-29.9) or obese $(>30.0)^{13}$. Total maternal weight gain during pregnancy was recorded on admission to delivery ward.

Blood pressure measurements at all clinic sites were taken according to a standardized published protocol, and all urine specimens were assessed for protein using dipsticks.

Mild preeclampsia was defined by the occurrence of two or more systolic blood pressure readings $\geq 140 \mathrm{mmHg}$ and/or diastolic pressure $\geq 90 \mathrm{mmHg}$, with the first elevated blood pressure occurring after 20 weeks of gestation up to 24 hours after delivery, combined with proteinuria of at least $0.3 \mathrm{~g}$ or " $1+$ protein" per 24 hours ${ }^{14,15}$.

Severe preeclampsia was defined as a systolic blood pressure of $160 \mathrm{mmHg}$ or greater and a diastolic blood pressure of $110 \mathrm{mmHg}$ or greater on at least two occasions at least 4 hours apart or on one occasion if antihypertensive therapy was administered. Severe proteinuria was defined with a 24-hour urine sample containing $\geq 3.5 \mathrm{~g}$ of protein or two urine samples of " $3+$ protein" or greater, taken at least 4 hours apart. The syndrome of haemolysis, elevated liver enzymes, and low platelets and eclampsia was also categorized as severe $\mathrm{PE}^{14,15}$.

\section{Statistical analysis}

Quantitative data are presented as mean \pm standard deviation and relative number of subjects in each category Student's t test, chi-square test and Spearman correlation coefficient, were used to evaluate the statistical significance of differences between normal and preeclamptic patients. For all comparisons, two-tailed tests were accepted as significant when $\mathrm{p}<0.05$.

\section{Results}

Table 1 shows the demographic and clinical characteristics of the women studied. Normo- tensive and preeclamptic women had similar age and parity.

There was a decreased risk of mild and severe preeclampsia among women who smoked during pregnancy. The impact of smoking on preterm delivery and/or lower birth weight was not analyzed.

Women who developed preeclampsia had higher rates of overweight prior to pregnancy and gained more weight during pregnancy. Mean weight gain during pregnancy in control and preeclamptic women was $13.9 \pm 3.1$ and $19.8 \pm$ $5.2 \mathrm{~kg}$, respectively $(\mathrm{p}<0.01)$.

Women with preeclampsia had significantly shorter gestations than their controls $(\mathrm{p}<0.01)$ and their offspring had a lower weight and length at birth.

Blood pressure values, especially diastolic and mean pressure had a direct correlation with the severity of preeclampsia.

Systolic, diastolic and mean blood pressure of normotensive and preeclamptic women at 6-12, 25-27, 32-33, 36-37, 39-40 weeks of gestation and during postpartum are shown in tables 2, 3 and 4. Preeclamptic women had significantly higher blood pressure, even before the onset of $\mathrm{PE}(\mathrm{p}<$ $0,01)$.

\section{Discussion}

Preeclampsia is a major cause of maternal and neonatal morbidity and mortality worldwide, although the etiology of preeclampsia is still unclear. Some studies concluded that the major phenotype of $\mathrm{PE}$, hypertension and proteinuria, may be due to an excess of circulating antiangiogenic growth factors, most notably soluble fms-like tyrosine kinase 1 (sFlt1) and soluble endoglin (sEng) $)^{10,16}$. The main focus of PE and its symptomatology is arterial hypertension. Diastolic blood pressure, related to arteriolar spasm, causes a permanent damage of blood circulation and has a primary influence in the disease. Recommendations adopted by the WHO state that systolic pressure is more variable than diastolic pressure and that itdoes not make any contribution toward the diagnostic or prognostic significance of the hypertensive disorders of pregnancy. There is little evidence to support this asseveration ${ }^{17}$.

The importance of blood pressure measurements during pregnancy has been recognized for more than a century (Seligman, 1987) and is 
Table 1. Description of maternal characteristics and pregnancy outcome by study groups*

\begin{tabular}{|c|c|c|c|}
\hline Characteristics & $\begin{array}{l}\text { Controls normal pregnancies } \\
\qquad n=300\end{array}$ & $\begin{array}{l}\text { Preeclamptic group } \\
\qquad n=100\end{array}$ & p value \\
\hline Maternal age (years) & $27.52 \pm 5.04(17-42)$ & $28.03 \pm 5.86(16-43)$ & \multirow{6}{*}{$>0.05^{\dagger}$} \\
\hline$<20$ & 5.33 & 9 & \\
\hline $20-25$ & 29.0 & 31 & \\
\hline $26-30$ & 40.0 & 27 & \\
\hline $31-35$ & 21.0 & 21 & \\
\hline$>35$ & 4.67 & 12 & \\
\hline \multicolumn{4}{|l|}{ Parity (\%) } \\
\hline Primipara & 46.67 & 64 & \multirow{2}{*}{$<0.05^{\ddagger}$} \\
\hline Multipara & 53.33 & 36 & \\
\hline \multicolumn{4}{|l|}{ Education (years) } \\
\hline $0-8$ & 27.66 & 47 & \multirow{3}{*}{$<0.01^{\dagger}$} \\
\hline $9-12$ & 53.0 & 38 & \\
\hline$>12$ & 19.34 & 15 & \\
\hline \multicolumn{4}{|l|}{ Profession (\%) } \\
\hline Housewife & 54 & 63 & \multirow{3}{*}{$>0.05^{\dagger}$} \\
\hline Physical Worker & 20,67 & 13 & \\
\hline Office Worker & 25,33 & 24 & \\
\hline Smokers (\%) & 10.33 & 2 & $<0.05^{\ddagger}$ \\
\hline \multicolumn{4}{|l|}{ Nationality (\%) } \\
\hline Macedonian & 83.67 & 68 & \multirow{3}{*}{$<0.01^{\dagger}$} \\
\hline Muslim & 14 & 31 & \\
\hline Other & 2.33 & 1 & \\
\hline BMI & $22.65 \pm 1.698(19.06-27.63)$ & $25.03 \pm 5.86(21.86-29.06)$ & $<0.01^{\S \S}$ \\
\hline$<19.99$ & 1.67 & 0 & \multirow{3}{*}{$<0.001^{\dagger}$} \\
\hline 20.0-24.99 & 87.33 & 26 & \\
\hline$>25.0$ & 11.0 & 74 & \\
\hline Weight gain (kg) & $13.95 \pm 3.1(7-29)$ & $19.81 \pm 5.21(10-39)$ & $<0.001^{\S}$ \\
\hline Duration of pregnancy & $39.57 \pm 0.9(37-42)$ & $38.56 \pm 1.58$ & $<0.001^{\text {s }}$ \\
\hline Birth weight (g) & $3427.77 \pm 332.36$ & $2855 \pm 366.72$ & $<0.001^{\S}$ \\
\hline Birth length $(\mathrm{cm})$ & $50.65 \pm 1.2$ & $47.93 \pm 2.03$ & $<0.001^{\S}$ \\
\hline \multicolumn{2}{|l|}{ Birth weight in percentile for GA } & 15 & \multirow{6}{*}{$<0.001^{\dagger}$} \\
\hline$<5$ & 0 & 26 & \\
\hline $5-9.90$ & 3 & 69 & \\
\hline $10-89.90$ & 93.33 & 0 & \\
\hline $90-94.9$ & 1.34 & 0 & \\
\hline$>95$ & 2.33 & & \\
\hline
\end{tabular}

*Data are given as mean, standard deviation and range. $-\mathrm{n}=$ number of subjects; $\mathrm{GA}=$ gestational age; $\mathrm{BMI}$ - body mass index. ${ }^{\dagger}$ chi-square test. ${ }^{\ddagger}$ chi-square test $2 \times 2$ contingency table. ${ }^{\S}$ Student's $t$ test. ${ }^{\S}$ Spearman correlation coefficient. 
Table 2. Average values of systolic blood pressure ( $\mathbf{m m H g})$

\begin{tabular}{|c|c|c|c|c|}
\hline Week of gestation & group & $\mathbf{n}$ & Average values* & p value \\
\hline \multirow{2}{*}{$6-12$} & control & 300 & $102.18 \pm 7.38$ & \multirow{2}{*}{$<0.01$} \\
\hline & preeclamptic & 100 & $112.6 \pm 9.36$ & \\
\hline \multirow{2}{*}{$25-27$} & control & 300 & $107.55 \pm 6.49$ & \multirow{2}{*}{$<0.01$} \\
\hline & preeclamptic & 100 & $125.3 \pm 13.33$ & \\
\hline \multirow{2}{*}{$32-33$} & control & 300 & $108.95 \pm 6.46$ & \multirow{2}{*}{$<0.01$} \\
\hline & preeclamptic & 100 & $136.2 \pm 16.94$ & \\
\hline \multirow{2}{*}{$36-37$} & control & 300 & $111.45 \pm 5.38$ & \multirow{2}{*}{$<0.01$} \\
\hline & preeclamptic & 96 & $148.85 \pm 15.4$ & \\
\hline \multirow{2}{*}{$39-40$} & control & 186 & $113.19 \pm 5.39$ & \multirow{2}{*}{$<0.01$} \\
\hline & preeclamptic & 32 & $142.03 \pm 17.68$ & \\
\hline \multirow{2}{*}{ Postpartum } & control & 300 & $117.82 \pm 3.34$ & \multirow{2}{*}{$<0.01$} \\
\hline & preeclamptic & 100 & $121.25 \pm 5.61$ & \\
\hline
\end{tabular}

- $\mathrm{n}=$ number of subjects; *Data are given as mean and standard deviation; 'Student's $\mathrm{t}$ test.

Table 3. Average values of diastolic blood pressure $(\mathbf{m m H g})$

\begin{tabular}{|c|c|c|c|c|}
\hline Week of gestation & group & $\mathbf{n}$ & Average values* & p value ${ }^{\dagger}$ \\
\hline \multirow{2}{*}{$6-12$} & control & 300 & $63.72 \pm 4.87$ & \multirow{2}{*}{$<0.01$} \\
\hline & preeclamptic & 100 & $74.05 \pm 9.61$ & \\
\hline \multirow{2}{*}{$25-27$} & control & 300 & $67.92 \pm 4.72$ & \multirow{2}{*}{$<0.01$} \\
\hline & preeclamptic & 100 & $83.0 \pm 9.61$ & \\
\hline \multirow{2}{*}{$32-33$} & control & 300 & $69.63 \pm 4.59$ & \multirow{2}{*}{$<0.01$} \\
\hline & preeclamptic & 100 & $91.55 \pm 11.93$ & \\
\hline \multirow{2}{*}{$36-37$} & control & 300 & $71.37 \pm 3.89$ & \multirow{2}{*}{$<0.01$} \\
\hline & preeclamptic & 96 & $100.1 \pm 10.6$ & \\
\hline \multirow{2}{*}{$39-40$} & control & 186 & $71.48 \pm 2.72$ & \multirow{2}{*}{$<0.01$} \\
\hline & preeclamptic & 32 & $92.5 \pm 3.53$ & \\
\hline \multirow{2}{*}{ Postpartum } & control & 300 & $74.3 \pm 4.35$ & \multirow{2}{*}{$<0.01$} \\
\hline & preeclamptic & 100 & $78.65 \pm 4.65$ & \\
\hline
\end{tabular}

- $\mathrm{n}=$ number of subjects; * Data are given as mean and standard deviation; 'Student's t test.

a fundamental part of antenatal care. For many women their pregnancy will be the first point of medical contact and they may have been unaware of any pre-existing hypertension up to this point ${ }^{18}$.

By design, the groups in our study did not differ by age. The percentage of nulliparous women was significantly higher among those with $\mathrm{PE}$. Women with less educational attainment had a higher risk of PE. Macedonian women had a lower risks of PE, compared to Muslims (Albanians and Turks). However, Muslim women had also a lower degree of education; twenty five of 31 were housewives and 23 had less than 8 years of education.

According to previous publications, $\mathrm{PE}$ is more common in patients who during were performing heavy physical activities pregnancy and in profes- 
Table 4. Average values of mean arterial pressure $(\mathbf{m m H g})$

\begin{tabular}{|c|c|c|c|c|}
\hline Week of gestation & group & $\mathbf{n}$ & Average values* & p valuet \\
\hline \multirow{2}{*}{$6-12$} & control & 300 & $76.54 \pm 5.4$ & \multirow{2}{*}{$<0.0001$} \\
\hline & preeclamptic & 100 & $86.9 \pm 8.01$ & \\
\hline \multirow{2}{*}{$25-27$} & control & 300 & $81.12 \pm 5.2$ & \multirow{2}{*}{$<0.0001$} \\
\hline & preeclamptic & 100 & $97.1 \pm 10.67$ & \\
\hline \multirow{2}{*}{$32-33$} & control & 300 & $82.74 \pm 4.9$ & \multirow{2}{*}{$<0.0001$} \\
\hline & preeclamptic & 100 & $106.5 \pm 13.48$ & \\
\hline \multirow{2}{*}{$36-37$} & control & 300 & $84.72 \pm 4.02$ & \multirow{2}{*}{$<0.0001$} \\
\hline & preeclamptic & 96 & $116.28 \pm 11.96$ & \\
\hline \multirow{2}{*}{$39-40$} & control & 186 & $85.56 \pm 2.86$ & \multirow{2}{*}{$<0.0001$} \\
\hline & preeclamptic & 32 & $109.0 \pm 8.25$ & \\
\hline \multirow{2}{*}{ Postpartum } & control & 300 & $88.82 \pm 3.5$ & \multirow{2}{*}{$<0.0001$} \\
\hline & preeclamptic & 100 & $92.8 \pm 4.46$ & \\
\hline
\end{tabular}

- $\mathrm{n}=$ number of subjects; *Data are given as mean and standard deviation; 'Student's $\mathrm{t}$ test.

sional workers, which may be related to stressful situations ${ }^{11,12}$. In our study, PE developed more often in housewives. Moreover, a lower level of education increased the risk of developing PE.

It is well known that smoking is a strong and common risk factor for low birth weight. Smoking seems to be negatively associated with PE. Thus, adjusting for smoking would increase rather than decrease the effect of PE in infants' weight ${ }^{14}$.

Women who developed preeclampsia had higher rates of overweight prior to pregnancy and gained more weight during pregnancy. These findings confirm previous findings that prepregnancy $\mathrm{BMI}$ is a strong independent risk factor for preeclampsia. Inflammation and lipids levels at first and second trimesters may be important mediators of the BMI- preeclampsia association.

In the present study, PE was associated with lighter, shorter and leaner newborns, compared to newborns from normal pregnancies. These results are similar to previous reports in the literature ${ }^{19,20}$.

We found marked differences in blood pressure between groups. However it must be emphasized that these differences were present even before the onset of PE (before 20 weeks of gestation).

Cnossen SJ et al (2008), reviewed 34 studies including 60,599 women, among which 3,341 had preeclampsia. They focused their review on diastolic and mean blood pressure but not on systolic pressure. They concluded that a diastolic blood pressure over $75 \mathrm{mmHg}$ in the period of $13-20 \mathrm{wg}$, had predictive importance. They also concluded that in the same period, mean arterial pressure values over $85-90 \mathrm{mmHg}$ also had predictive importance for the development of PE, which was also the case in our research ${ }^{21}$.

After childbirth, blood pressure between groups did not differ. This proves that delivery is the only real cure for pre-eclampsia.

Early diagnosis of hypertension has important implications for the management and prognosis of both the mother and the fetus. It is dependent on the accurate measurement of blood pressure, as hypertension is often the only early sign of impending PE. It is not, however, necessarily indicative of PE or eclampsia ${ }^{21}$.

Our study has limitations. We did not assess the combined effects of smoking and weight among women developing preeclampsia. We did not investigate and analyze the effect of diet, physical activity and the use of vitamin supplements during pregnancy.

Based on our results we stress that preeclampsia develops more frequently in primiparas. Housewives, illiterate women and women with lower education levels have the higher risk. The development of PE is preceded by obesity. The measurement of blood pressure can be used to predict the development of PE since there are differences between hypertensive and normotensive groups even before the onset of $\mathrm{PE}$. 
To reduce the level of perinatal morbidity and mortality in PE, a regular and organized surveillance of every pregnancy is necessary. With better antenatal protection, we can influence perinatal morbidity and mortality.

Acknowledgements: To Prof. Dr. Tatjana Ille for her assistance in statistical analysis and interpretation of data. To Prof. Dr. Mladenko Vasiljevic, for helpful comments regarding the manuscript.

\section{References}

1. Myers JE, Baker PN. Hypertensive diseases and eclampsia. Curr Opin Obstet Gynecol 2002; 14 (2): 119-25.

2. Duley L. Pre-eclampsia and the hypertensive disorders of pregnancy. Br Med Bull 2003; 67: 161-76.

3. Jovanović R, Đukić M. Hipertenzija u trudnoći. In: Opstetricija II. Dinulović D. editor. Beograd: Novinsko- izdavačka ustanova Službeni list 1996: 898-912 (Serbian).

4. Branch WD, Porter FT. Hypertensive Disorders of Pregnancy In: Danorth's Obstetrics and Gynecology. JR Scott, et al., editors. Philadelphia: Lippincot Williams \& Wilikins; 1999.

5. Smith RA, Baker PN. Risk factors, prevention and treatment of hypertension in pregnancy. Minerva Gynecol 2005; 57 (4): 379-88.

6. Barton JR, Bergauer NK, Jacques DL, Coleman SK, Stanziano GJ, Sibai BM. Does advanced maternal age affect pregnancy outcome in women with mild hypertension remote from term? Am J Obstet Gynecol 1997; 176 (6): 1236-43.

7. Dinulović D, Tulić I. Višestruka trudnoća. In: Opstetricija I. Dinulović D. editor. Beograd: Novinsko-izdavačka ustanova Službeni list SRJ 1996: 315-29.

8. Cvetković M, Ljubić A. Normalan i patološki rast ploda. In: Opstetricija II. Dinulović D. editor. Beograd: Novinsko-izdavačka ustanova Službeni list SRJ; 1996: 561-94.

9. Zhao SC. The relation between the levels of serum lipid peroxide, superoxide dismutase and atrial natriuretic peptide in placenta, umbilical cord vein and intrauterine growth retardation in pregnancy induced hypertension. Chung Hua Fu Chan Ko Tsa Chih 1993; 28 (5): 278-80.

10. Tjoa ML, Levine RJ, Karumanchi SA. Angiogenic factors and preeclampsia. Front Biosci 2007; 12: 2395-402.

11. Bobrowski RA, Bottoms SF. Underappreciated risks of the elderly multipara. Am J Obstet Gynecol 1995; 172: 1764-70.

12. Sibai MB, El-Nazer A, Gonzales-Ruiz A. Severe pre- eclampsia- eclampsia in young primigravid women. Subsequent pregnancy outcome and remote prognosis. Am J Obstet Gynecol 1996; 155 (5): 1011-6.

13. National Heart, Lung, and Blood Institute. Clinical guideline on the identification, evaluation, and treatment of overweight and obesity in adults. Available at: http:// www.nhlbi.nih.gov/guidelines/obesity/ob_gdlns.pdf. Accessed November 27, 2000.

14. Glanville T, Walker JJ. Management of mild pre-eclampsia. In: Pre-eclampsia, Etiology and Clinical Practice. Lyall F, Belfort M. Eds. 357-68. Cambridge University Press, Cambridge, 2007.

15. Walker PS, Permezel M, Brennecke PS, Ugoni MA, Higgins RJ. Blood pressure in Late Pregnancy and work outside the home. Ob Gyn 2001; 97: 361-5.

16. Mutter WP, Karumanchi SA. Molecular mechanisms of preeclampsia. Microvasc Res 2008; 75 (1): 1-8.

17. Shenann AH, De Greeff A. Measuring blood pressure in pregnancy and pre-eclampsia. In: Pre-eclampsia, Etiology and Clinical Practice. Lyall F, Belfort M. Eds. 258-75. Cambridge University Press, Cambridge, 2007.

18. Ness BR, Zhang J, Bass D, Klebanoff AM. Interreaction between smoking and weight in pregnancies complicated by preeclampsia and small-for-gestational age. Am J Epidemiol 2008; 168 (4): 427-33. Doi 10.1093/aje/ kwn140.

19. Ramussen S, Irgens ML. History of fetal growth restriction is more strongly associated with severe rather than milder pregnancy-induced hypertension. Hypertension 2008; 51: 1231-8

20. Coutts J. Pregnancy-induced hypertension-the effects on the newborn. In: Pre-eclampsia, Etiology and Clinical Practice. Lyall F, Belfort M. Eds. 506-21. Cambridge University Press, Cambridge, 2007.

21. Cnossen SJ, Vollebergt CK, de Vrieze N, ter Riet G, Mol WJB, Franx A, et al. Accuracy of mean arterial pressure and blood pressure measurements in predicting preeclampsia: systematic review and meta analysis. BMJ, 2008; 336: 1117-20.

22. Walsh AC, Baxi VL. Mean arterial pressure and prediction of pre-eclampsia. BMJ 2008; 336: 1079-80.

23. Baumwell S, Karumanchi SA. Pre-eclampsia: Clinical manifestation and molecular mechanisms. Nephron Clin Pract 2007; 106 (2): 72-81.

24. Didly GA, Belfort MA, Smulian JC. Preeclampsia recurrence and prevention. Semin Perinatol 2007; 31 (3): 135-41

25. Askie LM, Duley L, Henderson- Smart DJ, Stewart AL. Antiplatelet agents for prevention of preeclampsia: a meta analysis of individual patient data. Lancet 2007 26; 369 (9575): 1791-8. 